\title{
AN EXPLORATION OF SEXTING BEHAVIOR AMONG YOUTH AND THE ASSOCIATED LEGAL RAMIFICATIONS
}

\author{
Jennifer Breese-Vitelli D.Sc., Robert Morris University, vitelli@rmu.edu
}

\begin{abstract}
Harsh legal consequences for sending sexually explicit pictorial images through short message system (SMS) technology, more commonly known as sexting, do not consider changes in group behavior among youth based on the adoption of new technologies used for communication. Sexting, when not carried out with malice, should be understood to help understand patterns of 'normal' behavior among participants and assist law enforcement apply a reasonable response to the behavior. This paper explores sexting among youth as a cultural norm and addresses current legal consequences for the act. Ultimately raising the question what should be done to educate youth on the ramifications of the use of the behavior.
\end{abstract}

Keywords: Texting, Sexting, Mobile Technology

\section{PROBLEM}

Teens in Pennsylvania have been some of the first youths in the United States to be prosecuted harshly for a sending sexually explicit pictorial images through short message system (SMS) technology, but harsh consequences do not take into consideration the future unintended consequences of the imposing severe laws developed for other acts, the meaning the messages have to the teens sending and receiving them, and the cohort of youth who develop meaning from this type of social interaction. This paper will explore possible motivations for SMS text messages sent among a youth population, current legal consequences, and suggest future considerations when law enforcement is addressing the behavior through a secondary review of the literature on the topic.

\section{BACKGROUND}

Short Message System (SMS) also referred to as text messaging are written communications limited in characters sent from a cellular phone. Photographic images are also able to be sent through SMS with the addition of a camera to cellular technology. Just as technology is changing, societal norms for methods of communication and information among teens are also changing. Text messages are used as a medium to maintain relationships, but they can also be used as a means to perpetuate what would be considered deviant behavior both in society and under the law. Text messaging and photo transmission provide an impersonal venue for communication previously viewed as intimate. The term sexting has been used to describe the convergence of texting and sending sexually explicit images through SMS technology. The need to understand the social and cultural interpretations of sexting is important to determine what consequences, if any, are appropriate.

Technological innovations which involved the mobile phone began as early as the 1940's but the boon for the technology did not occur until the 1990's. The technology currently known as (SMS) text messaging began during a design of Groupe Speciale Mobile (GSM), a group that designed the specifications for the first digital cellular system to enable a mobile phone to be used on any network that had GSM equipment. Global Systems Mobile Communications was a term later used to describe the acronym (Taylor \& Vincent, 2005). The idea of associating cellular phones solely with mobility has been changed by young people who have transformed the definition of mobility. Young people might use cellular phones in close proximity to one another including while they are in the same room (Lachohee, Wakeford, \& Pearson, 2003).

Text messages were not originally thought of as a medium that would that would become a dominant trend among young people. The phone call itself seemed like it would be the ultimate intended goal for communication; but, through a combination of actors, companies, previous technologies, etcetera a collective process of interacting parts lead to the development of SMS messaging into the ubiquitous form of communication it is today. The 160 character limit and the multi-tap method for typing text messages led young people to explore and adapt their 


\section{Issues in Information Systems}

Volume XII, No. 1, pp. 114-119, 2011

communication styles to a hybrid style that became a new linguistic form of communication. The new abbreviated style began on the internet and made a transition to SMS messaging. When picture messaging on the cellular phone became available, utilization was not left up to the public at large to rise to the level of popularity of SMS messaging, companies began vigorous marketing campaigns that seemed to support a build it and they will use it approach. It was found that the pictures transmitted lacked the communal interplay or the show-and-tell aspects important with traditional forms of social interaction and began to be seen as a brazen form of narcissism telling receivers to look at them (Taylor \& Vincent, 2005).

Eldridge and Grinter (2001) identified a starting point for the way the behavior began among teens and the evolutions in behavior. "Communications patterns are shifting among teens as their array of options grows, (Lenhart, et al, 2007)". While number of teens overall prefer phone and face-to-face conversations those that use multiple technologies for communication prefer cell phones, instant messaging and social networking. A study of undergraduates' text messages by Thurlow (2003) revealed that only one-third of text messages accomplished a task. Respondents reported that their messages were friendship maintenance, romantic, and social interactions that were highly intimate (as cited in D. Reid, F. Reid, 2004).

Kuhn (1996) framed a process for the emergence of new dominate technologies which once accepted serves as a replacement to a previous technology. Kuhn's theory contended that when a technology is accepted by a culture as a new or better technology replacing the old one a paradigm shift has occurred. Previous to the occurrence of the paradigm shift a technology needs to be researched. Normal science is the next process after research, it is the process of going along as usual in which technology continues to advance but a radical change does not occur. The process moves from normal science when an anomaly occurs and then a scientific revolution or paradigm shift could occur. If the technology is not viewed as better or as a trusted technology it will not pass into the paradigm shift phase but rather return to the normal science stage. A technology may pass through the normal science stage many times before it reaches a scientific revolution (Kuhn, 1996). Text messages may have replaced other intimate types of communication rituals in the development among teens following this process.

\section{BACKGROUND: SEMIOTICS}

How do participants maneuver relationships when there are diminishing social cues as a result of conducting, building, and maintaining a relationship through text messaging? Text Messages are not completely void of social cues; they may be substituted with some other semiotic referent that indicates voice (Dwyer, n.d.). A precursor to the study of Semiotics is the science of symbolism. Ogden and Richards (1923) explored how we construct the meaning of meaning. They explained logistics and semiotics without complex laws of grammar; semiotics is the study of signs they term it the 'science of symbolism'. While the spoken word is the most important instrument in civilization, symbols and the relationship between words is paramount in linguist studies. In their work, which is more psychological in nature, they developed the beginnings of the semiotic triadic approach to communication that included the importance of the referent or what the sign stands for in the semiotic relationship (Ogden \& Richards 1923). Semiotics in broad terms is a study of signs and a further definition is what is meant by signs. The main claim is that semiotics represents a challenge to the literal because it rejects the notion that we can neutrally represent the way things are without interpretation of the mind or language. We as humans are always searching for meaning for things through words or signs. Two models heavily defined and reviewed by Chandler (2007) are the Peircean Model by philosopher Charles S. Peirce and the Saussurean Model developed by linguist Ferdinand de Saussure. Many individual signifiers make up one sign, all meaning individual things, as well as contributing to the meaning of the sign. Signifier is the form or practice a sign takes. The signified is the reference to the reality that is created. We therefore accept the meaning generated by the relationship between the signifier and the signified based on the social and cultural conventions we have learned (Chandler, 2007). The new language symbols that have been formed, their individual meaning, and more importantly what they signify among peer groups is crucial in identifying stages in a relationship when sext messages might appear. 


\section{BACKGROUND: CULTURE AND BEHAVIOR}

Descriptions of culture provided by Geertz (1973) were influential in the field of Anthropology and provided examples of thick cultural descriptions. Geertz had no overarching theory but said, culture is "a system of meanings embodied in symbols" that provide people with a frame of reference to understand reality and behavior (Geertz, 1973). Culture fills the gap between biological givens for our species and those things we need to function in a complex, interdependent and changing world. Is sexting a cultural norm among teens that is viewed with a meaning that ranges from onerous to completely deviant? Does sexting simply enable intimacy that is more closely utilizing technology in the same manner motor vehicles enabled "parking" among similar cohorts several generations ago?

The culture frame gleaned from Spradley (1989) stated that when ethnographers study other cultures they must deal with three aspects of the human experience: what people do, what people know, and the things people make and use. When these aspects of culture are learned and adopted by the members of a group they are referred to as cultural behavior, cultural knowledge, and cultural artifacts (Spradley, 1989). Frames identify what is noticed in a culture. The theatric frame described at great lengths by Goffman (1967) detailed the interaction and interdependence between the actors and the audience in the theatre. Actors are reading each other and the audience is interpreting their actions. The theatergoer submits to the world of the unreal developed by the scripted actors. Teens are experiencing the theatric by engaging in sexting behavior as a ritual in a world of the unreal where they are acting out a persona to assist in the relationship development without a mature understanding of consequences because consequences only exist outside of the theatre. Everyday life is a series of multiple changing frames (Goffman, 1967). Blumer (1998) has three premises with regard to symbolic interaction. The first premise is that people react to the meaning something has to them. The second, the meaning something has comes from a social interaction with others. The third, meanings go through a process of interpretation. Meaning is not a neutral method of understanding human behavior (Blumer, 1998). To properly charge or legislate the act of sexting the meaning of the actor should be considered as should the meaning of the act with regard to the peer group that interprets the act as a social interaction. Consideration of these factors creates an environment poised for law enforcement to determine whether the act should be charged with harshness or a relative slap on the wrist. Participants behavior should reveal aspects of the culture they have created through the use of text messaging technology in a manner in which society deems to be an expression of deviance.

\section{DEVIANT TEXT MESSAGING BEHAVIOR}

Several of the first cases brought to court with regard to teens using cell phone technology to transmit sexual revealing pictorial images without obscuring were local to Pittsburgh, Pennsylvania. These cases prompted further review into the phenomenon known as sex texting. An amendment to Pennsylvania HB89(2180) (2009) relating to the possession of pornography relaxed its definition to clearly state intentional viewing. Without the amendment a teen could be charged with possession of pornographic images regardless of whether they were intentionally viewed or not. This distinction is an important, but a clear definition of what intentional means will be vetted through the trial of additional cases and or legislation.

The ramifications for children under the age of eighteen who engage in what could be determined as deviant behavior with text messaging could have serious implications in that sending or receiving images sexually explicit images is a felony for children under the age of eighteen under pornography laws. Proposed legislation would make the transmissions a second degree misdemeanor with a possible differentiation for a first offence of simply a fine and forfeiture of their mobile device (New Pennsylvania Law, 2010). Currently teens charged under the harsh child pornography legislation would be charged with a felony and be subject to the application of Megan's Law.

The New Jersey mother and proponent of the Megan's Law bill that requires a registration for convicted sex offenders has railed officials for using this law in connection with a fourteen year old girl for posting her nude pictures on the popular social networking site MySpace (Millman, 2007). Requiring registration of these teens under this law for the rest of their lives in whatever community they decide to live and work could have serious ramifications. A sex offender designation could limit employment opportunities, residence choices, and prompt hysteria by neighbors. The dangers of sending and receiving electronic images are not understood by youth and may 
not have an appropriate reaction by law enforcement. Policies regarding the use of new technology need to be reviewed with regard to new trends among youth involving technological communication. Bronson and Merryman (2009) used the classic experiment of the temptation paradigm to study the deviant behavior of lying among children. This study found that once children are better able to distinguish the truth from a lie, the more likely they are to lie. The likelihood of a child to engage in lying behavior was increased by the parents lying behavior both through encouraging "white lies" and children modeling parent behavior in truthfulness. The implications of the study are that once the participants are able to differentiate the behavior as abhorrent the more likely they are to engage in it; additionally, parent involvement is also a factor to be reviewed to see if it plays a role in sex texting. A second study by Bronson and Merryman (2009) addressed what the authors call the science of teen rebellion with regard to addressing lying to parents. Twelve possible lying areas were identified and a group of similar aged students were administered questions in a one-on-one interview setting. Their study found that parents who were most consistent in enforcing rules, have the most conversations with their kids, support autonomy and freedom in decision making have kids that are less likely to lie in a greater number of the twelve factors (Bronson \& Merryman, 2009). The Pew and Internet Life Project highlighted that parents and teens agree that teens are not as careful online and that teens do things that their parents would not approve of. Bad experiences are cited by teens as deterrents from using the internet (Lenhart, 2005). Similarly, this paper seeks to address that teens are not careful with regard to text messaging technology when the perception of intimacy or the elevation of the development of a meaningful relationship is present. Additionally, if the act was not conducted with malice harsh legal consequences are not warranted.

\section{OUTSIDE INFLUENCES FOR TEXTING}

Owning a cellular phone could be a barrier to entry in the act of texting but studies have shown an increase in owning cellular phones among teenagers to a steady 100\% rate of ownership. A 2005 study stated that nearly half of all teens owned a cellular phone while a study presented at a 2007 conference states that every study participant reported owning a cellular phone (Lenhart, Madden, \& Hitlin, 2005; Dwyer, n.d.).

Further exploration into the topic could occur to determine if adjustment to new situations particularly university environments can support a positive transition through the use of texting. Increased parental communication has been popularized with articles referencing parents as helicopter parents overly involved in the lives of their children. A thesis study by Manthe (2009) studied parents that had constant electronic communication with their children who were incoming college freshman to determine the effect on the transition to college. As would be expected, the number of communication instances differed between females and males; females communicated more often than males. Surprisingly, given the negative connotation associated with helicopter parents, the study found a positive correlation between increased parental communication and a positive adjustment to college. A university study was conducted to argue that the use of text messaging by university staff would ease the transition process for undergraduate students. The study found that students that experience wider social networks are crucial to transition and text messaging is a key factor in maintaining those social networks (Harley, Winn, Pemberton, \& Wilcox, 2007). As referenced in the above study the technology has uses that can be beneficial to behavior. Other benefits would follow if a further review of the matter were to occur; therefore, the determination that limiting or discontinuing the use of the technology all together would negate the positive aspects. Ellul (1990) stated that some technologies can have positive effect as long as a change also occurs in society. Change is possible if a political and socio-change occurs hand in hand with new technology (Ellul, 1990). Therefore, changes to address this behavior in the legal system are necessary accompanied by additional education.

\section{BEHAVIOR WITH OTHER TECHNOLOGIES}

Hensel (2008) studied the influence of technology on adolescent development. She contended that the introduction of new technologies influences culture and in turn the way adolescents communicate and develop relationships. An increased level of electronic communication could create a situation where a positive relationship among peripheral groups outside the immediate peer group is developed through text messaging. Relationships are developed among this group more quickly due to a variety of technological communication methods like blogging on MySpace. Hensel (2008) determined that online behavior is shaping and is shaped by cultural influences; by understanding this process reviewing adolescent behavior on blogging sites can assist is new counselor intervention types. An 


\section{Issues in Information Systems}

Volume XII, No. 1, pp. 114-119, 2011

exploration of the influence cell phone technology has had on teen development might reveal their use or misuse of the technology (Hensel, 2008). Eastin developed a study to develop cognitive models for why some online users adopt some behaviors while others do not (Eastin, 2005). Digital images, stills, and videos have a large role in teen life. A virtual conversation based on feedback provided is started at least sometimes based on image posting. Nine in ten teens that post photos online state that comments are made at least sometimes (Lenhart, et al, 2007). Feedback among their peers might be another indicator of the need to engage in deviant behavior with other technologies like text messaging.

\section{CONCLUSION}

Text messaging behavior among teens is creating a new type of interaction and meaning among teens. Sending sexually explicit images through text messaging when the intent is to build a relationship rather than an act of malice needs to be addressed as the norm of the cohort rather than a deviant behavior determined by society at large. New technologies have changed and will continue to change the way groups interact and the legal system will need to address the issues with legislation that speak to the act rather than applying laws not meant for new technology behaviors. An exploration of cases in which Megan's Law was applied, those in which it was not in Pennsylvania, and the dissection of the proposed law that is specific to the act of sexting, it might be determined that while the act might in some situations be a prosecutable offence, it is not the correct application of Megan's Law among the teen population. Further explorations should consider the intent of the actor, the interpretation of the peer-group when applicable, and both intended and non-intended consequences of the prosecution. Additionally, an exploration be made to determine where the responsibility of youth education including the type of education that would be most impactful with regard to the use of new technologies.

\section{REFERENCES}

1. An Act amending Title 18 (Crimes and Offenses) of the Pennsylvania Consolidated Statues, in minors, further providing for the offense of sexual abuse of children. HB 89 (2009)

2. Barton, S., Patterson, A., \& Harris, K. (2006). Beyond technology acceptance: understanding consumer practice. International Journal of Service Industry Management, 17(2), 111-135.

3. Berger, P. L. \& Luckmann, T. (1966). The social construction of reality: A treatise in the sociology of knowledge. New York: Anchor Books Doubleday.

4. Bronson, P., \& Merryman, A. (2009). NurtureShock: New Thinking About Children. New York: Twelve.

5. Brown, J., Vetter, R., \& Saunders-white, D. (2008). Enhancing mobile access to information with the short messaging service. Journal of Computing in Higher Education, 20(2), 24-34.

6. Caplan, S. (2003). Preference for Online Social Interaction: A Theory of Problematic Internet Use and Psychosocial Well-Being. Communication Research, 30(6), 625-648.

7. Chandler, D. (2003). Semiotics: the basics. New York and London: Routledge. (SB)

8. Cox, A., Cairns, P., Walton, A., \& Lee, S. (2008). Tlk or txt? Using voice input for SMS composition. Personal and Ubiquitous Computing, 12(8), 567-588.

9. Descy, D. E. (2007). IM set to talk with you text!. Tech Trends, 51(1), 3-6.

10. Dewey, .J. (1986). Logic: The theory of inquiry. In J. A. Boydston (Ed.), John Dewey: The later works, 19251953 (Vol. 12: 1938). Carbondale and Edwardsville: Southern Illinois University Press. (Original work published 1938).

11. Dwyer, C. (n.d.). Digital Relationships in the "MySpace" Generation: Results From a Qualitative Study. csis.pace.edu. Retrieved November 22, 2009, from csis.pace.edu/ dwyer/research/DwyerHICSS2007.pdf

12. Eastham, M. (2009). HEALING THE WOUNDED ADOLESCENT. Compass, 43(2), 2-15.

13. Eastin, M. (2005). Teen Internet Use: Relating Social Perceptions and Cognitive Models to Bahavior. Cyberpsychology and Behavior, 8(1), 62-75.

14. Eldridge, M. \& Grinter, R. (2001). Studying Text Messaging in Teenagers. Position Paper for CHI 2001 Workshop \#1, Mobile Communications: Understanding User, Adoption and Design.

15. Ellul, J. (1990). Ambivalence. Chapter One of The Technological Bluff. Grand Rapids: Eerdmans,35-76.

16. Flick, P. U. (1998). An Introduction to Qualitative Research. Thousand Oaks, CA: Sage Publications Ltd.

17. Geertz, C. (1973). The interpretation of cultures. New York: Basic Books.

18. Goffman, E. (1967). Interaction ritual: Essays on face-to-face behavior. Garden City, NY: Anchor Books 


\section{Issues in Information Systems}

Volume XII, No. 1, pp. 114-119, 2011

Doubleday.

19. Goffman, E. (1974). Frame analysis: An essay on the organization of experience. Boston: Northeastern University Press.

20. Harley, D., Winn, S., Pemberton, S., \& Wilcox, P. (2007). Using texting to support students' transition to university. Innovation in Education and Teaching International, 44(3), 229-241.

21. Kuhn, T. S. (1996). The structure of science revolutions ( $3^{\text {rd }}$ ed.). Chicago: The University of Chicago Press.

22. New Pennsylvania Law Criminalizing Teen "Sexting" Receives Mixed Reviews | Pittsburgh Criminal Attorney Blog. (2010.). Pittsburgh Criminal Attorney Blog | Pennsylvania Child Pornography Lawyer | Allegheny County Sex Crime Law Firm. Retrieved January 23, 2011, from http://www.pittsburghcriminallawattorney.com/2010/10/new-pennsylvania-law-criminalizing-teen-sextingreceives-mixed-reviews.shtml

23. Lacohee, H., Wakeford, N., \& Pearson, I. (2003). A social history of the mobile telelphone with a view of its future. BT Technology Journal, 21(3), 203-211.

24. Lenhart, A., Madden, M., Smith, A., \& Macgill, A. M. (2007, December 19). Teens and Social Media | Pew Internet \& American Life Project. Retrieved October 4, 2009, from http://www.pewinternet.org/Reports/2007/Teens-and-Social-Media.aspx

25. Lenhart, A., Madden, M., \& Hitlin, P. (2005, June 27). Teens and Technology | Pew Internet \& American Life Project. Retrieved October 4, 2009, from http://www.pewinternet.org/Reports/2005/Teens-andTechnology.aspx

26. Lenhart, A., \& Madden, M. (2005, November 2). Teen Content Creators and Consumers | Pew Internet \& American Life Project. Retrieved October 4, 2009, from http://www.pewinternet.org/Reports/2005/TeenContent-Creators-and-Consumers.aspx

27. Lenhart, A. (2005, March 17). Protecting Teens Online | Pew Internet \& American Life Project. Retrieved October 4, 2009, from http://www.pewinternet.org/Reports/2005/Protecting-Teens-Online.aspx

28. Manthe, T. (2009). Effects of Communication with Family on Adaptation to College of First-Year College Students Retrieved from Dissertations and Theses database.(AAT 3344217)

29. Millman, Jennifer (2009, 03, 27). Megan's law mom ok with nude MySpace teen. Retrieved August 21, 2009, from NBC New York.com Web site: http://www.nbcnewyork.com/news/local-beat/Girl-Charged-With-ChildPorn-for-Posting-Nude-Pics-of-Self.html

30. Ogden, C. K. \& Richards, I. A. (1923). The meaning of meaning: A study of the influence of language upon thought and of the science of symbolism. New York and London: Harcourt / HBJ Book Harcourt Brace Jovanovich.

31. Reid, D., \& Reid, F. (n.d.). Insights into the Social and Psychological Effects of SMS Text Messaging. 160 $\begin{array}{llll}\text { Characters. } & \text { October } & \text { Retrieved } & \text { 2009, from }\end{array}$ www.160characters.org/documents/SocialEffectsOfTextMessaging.pdf

32. Smith, W. S. (2005). Employers and the New Generation of Employees. Community College Journal, 76(3), 813.

33. Spradley, J. P. (1980). Participant observation. New York: Wadsworth Thomson Learning. Tanakinjal, G., Lajuni, N., \& Bolongkikit, J. (2007). Mobile Devices and Communication: An Analysis. Journal of Internet Banking and Commerce , 12(3), 1-9.

34. Taylor, A., \& Vincent, J. (2005). An SMS History. In L. Hamill \& A. Lasen (Ed.), Mobile World: Past, Present and Future (Computer Supported Cooperative Work) (pp. 75-91). New York: Springer.

35. Wisely, D. (2007). Cellular mobile - the generation game. BT Technology Journal, 25(2), 27-41. 